\title{
APROXIMACIÓN CUALITATIVA \\ A LAS POSICIONES DISCURSIVAS SOBRE LA PROSTITUCIÓN: PERSPECTIVA SOCIOEDUCATIVA'
}

\author{
A QUALITATIVE APPROACH \\ TO THE POSITIONS TOWARDS PROSTITUTION THROUGH SOCIAL \\ DISCOURSE: SOCIOEDUCATIONAL PERSPECTIVE
}

\section{ABORDAGEM QUALITATIVA \\ DAS POSIÇÕES DISCURSIVAS SOBRE A PROSTITUIÇÃO FEMININA: \\ PERSPECTIVA SOCIOEDUCATIVA}

\author{
María Carmen Delgado Álvarez y Andrea Gutiérrez García \\ Universidad Pontificia de Salamanca, España
}

\begin{abstract}
RESUMEN: El debate social sobre prostitución se polariza en dos posiciones básicas: erradicación y regulación. Estas posiciones emergen desde las representaciones sociales de las que participan quienes las adoptan. El objetivo de este estudio es aproximarse a los contenidos de su representación social en jóvenes estudiantes de universidad a través de las producciones discursivas mediante la técnica del grupo de discusión. Se formaron cuatro grupos de chicas, cuatro de chicos y uno mixto. El análisis de contenido a través del programa Nvivo 10, revela la presencia de ambas posiciones en el discurso y un marco común de definición. En la representación social emergente, el debate se centra en la mujer prostituida permaneciendo invisibilizado el hombre consumidor y los valores del modelo patriarcal de sexualidad. Ocupa un lugar preponderante la cuestión económico-laboral. Los argumentos en contra se articulan en torno a: (1) estigma y degradación para la mujer, (2) no legitimidad ética, (3) nunca es libre para las mujeres ni legítima para los hombres. Los argumentos a favor se articulan en torno a: (1) contrato libre entre personas, (2) cumple una función social, (3) no es degradante para las mujeres ni éticamente reprobable. El análisis de estos discursos es fundamental para una adecuada pedagogía social dirigida a promover valores de igualdad y a visibilizar posiciones de poder en las relaciones de género.
\end{abstract}

PALABRAS CLAVE: Análisis del discurso; Investigación cualitativa; Prostitución; Cuestiones de género; Concienciación; Educación Social.

ABSTRACT: The social debate on prostitution is polarized into two basic viewpoints or positions: abolition and regulation. These stances emerge from the Social representations of the people who participate in the 
debate. The aim of this study is to offer an approach to measure the social representation on the topic of prostitution in young university students using the group discussion technique. Four women's discussion groups, four men's groups and one mixed sex group were formed. The content analysis, made with the software Nvivolo, reveals the presence of both stances in the emerging social representation of the students and provides a common framework of definition.In the discussion groups, the focus is on women prostitutes staying hidden away, men as the consumer and the patriarchal model of sexuality that persists. The themes of economics and employment also form an important part of the discussions. The arguments against prostitution are articulated around: (1) stigma and degradation of women, (2) the lack of ethical legitimacy, (3) it's never a free choice for the women nor legitimate for the men $\mathrm{f}$. The arguments in favour are articulated around: (1) It's an agreement between people who are free to choose, (2) it fulfils a social function, (3) it's neither degrading nor ethically reprehensible for women. The analysis of these discourses is essential for an adequate social pedagogy aimed at promoting gender equality values and shedding light on positions of power in gender relations.

KEY WORDS: Discourse analysis, Qualitative Research, Prostitution, Gender issues, Consciousness Raising, Community education.

RESUMO: O debate social sobre a prostituição polariza-se em duas posições básicas: erradicação e regulamentação. Estas posições surgem a partir das representações sociais que envolvem aqueles que as adotam. O objetivo deste estudo é abordar os conteúdos da sua representação social em jovens universitários, através da produção discursiva utilizando a técnica de discussão em grupo. Formaram-se quatro grupos de raparigas, quatro de rapazes e um misto. A análise de conteúdo, através do programa Nvivo 10 revela a presença de ambas as posições no discurso e um quadro comum na definição. Na representação social emergente, o debate centra-se na mulher prostituída, permanecendo invisível o homem consumidor e os valores do modelo patriarcal de sexualidade. A questão económico-laboral ocupa um lugar preponderante. Os argumentos contra giram em torno de: (1) estigma e degradação para a mulher, (2) ausência de legitimidade ética, (3) nunca é livre para as mulheres nem legítimo para os homens. Os argumentos a favor giram em torno de: (1) livre contrato entre os indivíduos, (2) cumpre uma função social, (3) não é degradante para as mulheres nem eticamente reprovável. A análise destes discursos é fundamental para uma adequada pedagogia social que visa promover os valores de igualdade de género e tornar visíveis posições de poder nas relações de género.

PALAVRAS-CHAVE: Análise do Discurso; Investigação qualitativa; Prostituição; Questões de género; Conscientização; Educação comunitária.

[ 36 ] MARÍA CARMEN DELGADO ÁLVAREZ Y ANDREA GUTIÉRREZ GARCÍA

SIPS - PEDAGOGIA SOCIAL. REVISTA INTERUNIVERSITARIA [1139-1723 (2015) 26, 35-57] TERCERA ÉPOCA 


\section{Introducción}

\section{Representaciones sociales y acción transfor- madora de la educación}

El paradigma constructivista en la ciencia asume que la realidad no es, sino que se construye a partir de valores y creencias que filtran la percepción selectiva de la misma, dotándola de significado. Se trata, en suma, de una construcción de la realidad, resultado de la interacción entre factores individuales y factores sociales (Vygotsky, 1978; Piaget \& García, 1989; Watzlawick, 1980). El concepto de representación social permite abordar el modo en que las sociedades elaboran colectivamente las reglas y justifican las creencias cuyos significados comparten (Moscovici \& Hewstone, 1986; Jodelet, 1986; Ibáñez, 1988). Podemos considerarlas como maneras de interpretar la realidad cotidiana, que cumplen para los sujetos no sólo una función comprensiva de esa realidad, sino -y principalmente- una función de posicionamiento frente a los acontecimientos que les conciernen. Los juicios compartidos por el grupo es lo que legitima su verdad por consenso (Bueno, 2011).

La educación, en tanto que recurso para conseguir la igualdad entre hombres y mujeres, debe abordar todos los ámbitos en que se produce la discriminación de género, siendo uno de sus objetivos "suprimir todas las formas de trata de mujeres y explotación de la prostitución de la mujer" (BasPeña, 2014, p. 16). Esta tarea educativa requiere en ocasiones cuestionar creencias legitimadoras, que perpetúan formas ancestrales de discriminación haciéndolas parecer aceptables (Martín Baró, 2006; Martín Baró, Aron \& Corne, 1994). La educación/pedagogía social debe incluir por tanto el componente crítico que se espera de ella, ya que "en su naturaleza estructural se integran los objetivos transformadores de una realidad individual o social que puede $y$ debe mejorarse, ya porque tenga potencialidades, o porque tenga necesidades o carencias" (Ortega, 2008, p. 5).

En el caso de la prostitución ${ }^{2}$ cuyos efectos nocivos para las mujeres han sido ampliamente documentados (Meneses, 2007; Fernández, 2011; Heileman \& Santhiveeran, 2011) podemos plantear cuáles son las creencias compartidas que la legitiman socialmente, y a qué intereses sirven; en suma,

\section{Introduction}

\section{Social representations and transformative ac- tion in education}

The constructivist paradigm in science assumes that reality does not exist by itself, but it is built out of values and beliefs that filter it's selective perception, giving it a meaning. It is, in short, a construction of reality, the result of the interaction between individual factors and social factors (Vygotsky, 1978; Piaget \& Garcia, 1989; Watzlawick, 1980). The concept of social representation can address how societies collectively make rules and justify beliefs, the meanings of which are shared. (Moscovici \& Hewstone, 1986; Jodelet, 1986; Ibáñez, 1988). We can consider them as ways to interpret the daily reality, as for the subjects they have not only a comprehending function of that reality, but also a mainly positioning function to the events that concern them. The judgments shared by the group are what legitimizes their truth, by consensus (Bueno, 2011).

Education, while being a resource to achieve equality between men and women, must address all areas where gender discrimination occurs, one of its objectives being to "suppress all forms of traffic in women and exploitation of women prostitution "(BasPeña, 2014, p.16). This educational task sometimes requires the questioning of legitimating beliefs that perpetuate ancestral forms of discrimination making them look acceptable (Martín Baró, 2006; Martín Baró, Aron \& Corne, 1994). Education / social pedagogy must therefore include the critical component that is expected of it, because its structural nature integrates the objectives that transform an individual or social reality that can and must be improved, either because it has a potentiality, or because it has needs or is lacking something "(Ortega, 2008, p.5).

In the case of prostitution of which the harmful effects on women have been widely documented (Meneses, 2007; Fernandez, 2011; Heileman \& Santhiveeran, 2011) we can consider which are the shared beliefs that give it social legitimacy, and whose interests they serve, in short, what its purpose is and how people participate in these cultural meanings and elaborate arguments to rationalize previously assumed beliefs. 
cuál es su funcionalidad y cómo las personas que participan de estos significados culturales, elaboran argumentos para racionalizar las creencias previamente asumidas.

La educación/pedagogía social se convierte en espacio privilegiado para la intervención sobre las representaciones legitimadoras de las múltiples formas de explotación que adquiere la desigualdad de género, siendo la prostitución una de sus manifestaciones (Delgado \& Gutiérrez, 2012). Su relevancia no se refleja sin embargo, en los planes de estudios para profesionales de la educación (Bas-Peña, Pérezde-Guzmán \& Vargas, 2014). A pesar de los esfuerzos educativos realizados en los últimos años en materia de igualdad, "las normas que tradicionalmente han regido las prescripciones de género siguen vigentes" (González Pérez, 2010, p. 356). La prostitución emerge como caso paradigmático en el que operan las prescripciones tradicionales de género, atravesando la construcción de la sexualidad desde un modelo de masculinidad hegemónica (Bourdieu, 1998; Cobo, 2011).

\section{La prostitución como problema social y cues- tión educativa}

Las investigaciones sobre prostitución se han ocupado tradicionalmente de las mujeres prostituidas (De Paula, 2000; Osborne, 1991) y desde hace pocos años de los hombres consumidores (Barahona \& García, 2003; López \& Baringo, 2006; Meneses, 2007). Rara vez se realizan estudios sobre la población general, pese a ser el objetivo de la prevención socio-educativa.

La revisión de las creencias sostenedoras de la norma tradicional es la primera cuestión a la que habrá de enfrentarse cualquier acción educativa que pretenda un cambio o innovación social. Cuando estas creencias están profundamente instaladas en el imaginario colectivo, el cuestionamiento mediante el debate social es el primer elemento de cambio (Moscovici \& Olasagasti, 1981). En el caso de la prostitución todas las posiciones en litigio articulan los cauces argumentativos como "lo mejor para la sociedad", por lo que el conflicto se plantea entre argumentaciones. Es por ello, que los modelos organizadores del discurso se convierten en elementos claves para identificar los intereses a los que
Education / social pedagogy becomes an exceptional space for the intervention on legitimating representations of multiple forms of exploitation that gender inequality takes on, prostitution being one of its manifestations (Delgado \& Gutiérrez, 2012). Its relevance is not yet reflected in the study programme for education professionals (Bas-Peña Pérez de Guzmán \& Vargas, 2014). Despite educational efforts made in terms of equality in recent years, "the rules that have traditionally governed gender prescriptions remain valid" (González Pérez, 2010, p.356).Prostitution emerges as a paradigmatic case in which the traditional gender requirements operate, permeating the construction of sexuality with a model of hegemonic masculinity (Bourdieu, 1998; Cobo, 2011).

\section{Prostitution as a social problem and educatio- nal issue}

Research on prostitution has traditionally focused on female prostitutes (De Paula, 2000; Osborne, 1991) and for the last few years, on male consumers (Barahona \& Garcia, 2003; Lopez \& Baringo, 2006; Meneses, 2007). Studies on the general population are seldom made, despite being the target group of socio-educational prevention.

The revision of beliefs sustaining the traditional rule is the first issue that any educational action that seeks change or a social innovation will have to face. When these beliefs are deeply embedded in the collective imagination, the questioning through social debate is the first vehicle of change (Moscovici \& Olasagasti, 1981).In the case of prostitution all viewpoints at dispute argue their case as being "the best for society" so that the conflict arises between arguments. Therefore, organizational models of discourse have become key elements to identify the interests which they are functional for: 1) which elements of the reality of prostitution are selected to build the discourse, 2) what meanings are attributed to them, 3) what relationships are established

[ 38 ] MARÍA CARMEN DELGADO ÁLVAREZ Y ANDREA GUTIÉRREZ GARCÍA 
resultan funcionales: 1) qué elementos de la realidad de la prostitución se seleccionan para construir el discurso, 2) qué significados se les atribuye, 3) qué relaciones se establecen entre ellos, y 4) qué consecuencias se extraen (Moreno Marimón \& Sastre, 2010). El debate a partir de esta confrontación de ideas puede modificar la representación cognitiva, como ocurrió con la violencia de género (Delgado, Sánchez \& Fernández-Dávila, 2011). La Educación/Pedagogía Social puede encontrar en este debate nutrido con los resultados de investigación, instrumentos que le permitan desarrollar la acción crítica inherente a su naturaleza transformadora (Ortega, 2008).

Cuando se analiza la prostitución desde las teorías de género emergen claves antropológicas (Lagarde, 2011), filosóficas (De Miguel, 2012), sociológicas (Cobo, 2011) y psicológicas (Delgado \& Gutiérrez, 2012) que afectan a todo proceso educativo. Estas claves visibilizan "las prácticas de género y de control heteronormativo" (Carrera, 2013, p. 5) atravesando el sistema de dominación de la masculinidad tradicional hegemónica, dirimido en la apropiación de los cuerpos de las mujeres, más allá de sus concreciones históricas, y de la conciencia subjetiva de los actores concretos. Desvelar la violencia consustancial a la prostitución, invisibilizada bajo la forma de elección libre por parte de las mujeres que la ejercen (Gutiérrez, 2012), requiere desentrañar los argumentos discursivos con los que se entreteje su representación social, para poder cuestionar la carga "ideológica" subyacente (Billig, 1996). Se trataría, en suma, de abordar su "desideologización" en acciones educativas que permitan cuestionar "el afianzamiento de un orden social injusto" (Martín-Baró, 2006, p. 10).

\section{Objetivos}

Se plantea un estudio de carácter exploratorio para "determinar tendencias, identificar áreas, ambientes, contextos y situaciones de estudio, relaciones potenciales entre variables, o establecer el "tono" de investigaciones posteriores más elaboradas y rigurosas" (Hernández Sampieri, Fernández \& Baptista, 2010, p.102). No pretende por tanto, obtener conclusiones generalizables a la población a través de muestras estadísticamente representativas, sino amongst them, and 4) what consequences are deduced (Sastre \& Moreno Marimon, 2010).The discussion that comes out of this clash of ideas can change the cognitive representation, as occurred with gender violence (Delgado \& Fernández-Sánchez Dávila, 2011). Education / Social Pedagogy can find, in this extensive discussion of research findings, instruments that allow it to develop critical action inherent to its transformative nature (Ortega, 2008).

When prostitution is analyzed from the point of view of anthropological gender theories (Lagarde, 2011), philosophical (De Miguel, 2012), sociological (Cobo, 2011) and psychological keys (Delgado \& Gutiérrez, 2012) emerge that affect the entire educational process. These keys make it clear that "gender and heteronormative control practices" (Carrera, 2013, p. 5) through the traditional hegemonic masculinity domination system, are merely the appropriation of women's bodies, no matter the historical contexts, or the subjective awareness of specific actors. Revealing the inherent violence in prostitution, made invisible by the assumption of free choice for women who practise it (Gutiérrez, 2012), requires an unraveling of the discursive arguments that interweave its social representation, in order to challenge the "underlying ideological burden "(Billig, 1996).In short, it would be about addressing its "desideologization" in educational activities that allow the questioning of "the entrenchment of an unjust social order" (Martín-Baró, 2006, p.10).

\section{Goals}

An exploratory study is proposed to "determine trends, identify areas, environments, contexts and study situations, potential relationships between variables, or to set the" tone" of a more elaborate and rigorous further research" (Hernandez Sampieri, Fernández \& Baptista, 2010, p.102).It is not intended therefore to yield generalizable findings to apply to the population through statistically representative samples, but to approach the relationship between 
aproximarse a la relación entre emergentes en los discursos, que permitan nutrir el debate para una acción socioeducativa transformadora.

El objetivo de la investigación es obtener una aproximación a las categorías cognitivas que emergen en los discursos de jóvenes universitarios sobre la prostitución femenina, con el fin de aportar elementos para la intervención socioeducativa.

\section{Método}

\subsection{Técnica: grupo de discusión}

Desde un punto de vista psicolingüístico el discurso refiere la realidad física y psíquica percibida por la comunidad que comparte significados; no sólo representa una realidad accesible, sino una realidad percibida y significada de un modo determinado. El grupo de discusión crea un contexto social en el que las opiniones de sus participantes adquieren un sentido más próximo a la dinámica social: "si el universo del sentido es grupal (social), parece obvio que el formato del grupo de discusión habrá de adaptarse mejor a él que la entrevista individual por abierta (o en profundidad) que sea" (Canales \& Peinado, 1994, p.290). Se convierte pues en técnica privilegiada para analizar el discurso recreando "la estructuración simbólico-significante de los procesos de interacción" (Gurdián, 2007, p.207) y facilitando la aproximación metodológica a la presión o violencia semántica. El lenguaje, portador del componente simbólico del mundo cognitivo de los sujetos, se convierte en la vía de acceso a los modelos organizadores con los que las personas engarzan los elementos de la realidad social, siendo el grupo de discusión un recurso privilegiado para reproducir artificiosamente la "conversación" que es la vida social (Ibáñez, 1979).

\subsection{Participantes}

En estudios fenomenológicos cuyo objetivo es analizar valores y significados de un grupo social, el tamaño muestral queda determinado por la saturación de las categorías discursivas (Sánchez, Delgado \& Santos, 2012) por lo que la calidad de la muestra no reside en su representatividad estadística, sino en la riqueza y profundidad de la información recogida the emerging in discourses which allow the debate to nurture a transformative educational action.

The aim of the research is to obtain an approximation of the cognitive categories that emerge in the discourse of university students about female prostitution in order to provide elements for educational intervention.

\section{Method}

\subsection{Technique: discussion group}

From a psycholinguistic point of view the discourse speaks about the physical and psychological reality perceived by the community that shares meanings; it not only represents an accessible reality but a reality signified and perceived in a certain way. The discussion group creates a social context in which the opinions of the participants acquire a meaning closer to the social dynamics: "If the universe of meaning is a group (social), it seems obvious that the group discussion format will adapt better to it than an individual interview, as open (or in depth) as it may be "(Canales \& Peinado, 1994, p.290).It therefore becomes an exceptional technique to analyze the discourse, recreating "the symbolic- significant structure of the interaction processes" (Gurdián, 2007, p.207) and facilitating the methodological approach to the semantic pressure or semantic violence. The language, carrier of the symbolic component of the subjects' cognitive world, becomes the gateway to the models of organization with which people link the elements of social reality, the discussion group being a convenient resource to artificially reproduce the "conversation" that is the social life (Ibáñez, 1979).

\subsection{Participants}

In the phenomenological studies aimed at analyzing values and meanings of a social group, the sample size is determined by the saturation of discursive categories (Sanchez Delgado \& Santos, 2012) so the quality of the sample does not lie in its statistical significance, but in the richness and depth of information gathered until the speech is exhausted

[ 40 ] MARÍA CARMEN DELGADO ÁLVAREZ Y ANDREA GUTIÉRREZ GARCÍA SIPS - PEDAGOGIA SOCIAL. REVISTA INTERUNIVERSITARIA [1139-1723 (2015) 26, 35-57] TERCERA ÉPOCA 
hasta agotar el discurso (Hernández Sampieri, Fernández \& Baptista, 2010).

Se invitó a estudiantes de Grado en Psicología a participar voluntariamente en una ronda de debates en pequeños grupos sobre algunos problemas sociales, sin anticipar el tema específico que se abordaría en la discusión. Fueron seleccionados en el orden de inscripción, con el único criterio de cuotas equilibradas por sexo. Se consideró saturado el discurso cuando en un grupo no surgieron nuevas ideas sobre el objeto de estudio. La muestra final quedó conformada del modo siguiente:
(Hernandez Sampieri, Fernández \& Baptista, 2010).

Students of Psychology were invited to voluntarily participate in a round of small group discussions on some social issues, without anticipating the specific issue that was to be addressed in the discussion. They were selected in order of registration, with balanced gender quotas as the sole criteria. The discourse was considered to be saturated when no new ideas about the object of study emerged in the group. The final sample was made up as follows:

Tabla 1. Composición de la muestra por sexo y edad

\begin{tabular}{|l|l|l|}
\hline MUESTRA HOMBRES & MUESTRA MUJERES & MUESTRA TOTAL \\
\hline $\mathrm{N}=35$ & $\mathrm{~N}=36$ & $\mathrm{~N}=71$ \\
$\mathrm{Rango}=19-28$ años & Rango $=19-28$ años & Rango $=19-28$ años \\
Media $=20,89$ años & Media $=20,03$ años & Media $=20,45$ años \\
Desviación Típica $=1,81$ & Desviación Típica $=2,07$ & Desviación Típica $=1,98$ \\
No grupos: $4+1$ mixto & No grupos: $4+1$ mixto & No grupos: $8+1$ mixto \\
\hline
\end{tabular}

Table 1. Composition of the sample by sex and age

\begin{tabular}{|l|l|l|}
\hline MEN SAMPLE & WOMEN SAMPLE & WOMEN SAMPLE \\
\hline $\mathrm{NN}=35$ & $\mathrm{~N}=36$ & $\mathrm{~N}=71$ \\
$\mathrm{Age}$ Range $=19-28$ & Age Range $=19-28$ & Age Range $=19-28$ \\
Mean $=20.89$ years & Mean $=20.03$ years & Mean $=20.45$ years \\
Standard deviation $=1.81$ & Standard deviation $=2.07$ & Standard deviation $=1.98$ \\
Number of groups: $4+1$ mixed & Number of groups: $4+1$ mixed & Number of groups: $8+1$ Mixed \\
\hline
\end{tabular}

\subsection{Procedimiento}

Por las características del tema se controló el sexo de la persona moderadora, siendo una investigadora en el grupo de mujeres y un investigador en el de hombres. El grupo mixto fue moderado por ambos. Una vez presentados los participantes entre sí, se comunicaba el tema de la discusión subrayando que se trataba de intercambiar ideas, sin que unas fueran mejores que otras, ya que distintas opiniones sólo reflejaban distinto modo de pensar. A continuación se recogía el consentimiento para grabar en vídeo las sesiones, con el fin de transcribirlas, analizarlas, y destruirlas posteriormente. En ese momento se informaba que se podía abandonar el grupo si el tema resultaba poco interesante, facilitando así una excusa aceptable a quienes pudieran sentir incomodidad.

\subsection{Procedure}

Due to nature of the subject matter, the gender of the moderator was taken into account, being a female researcher in the group of women and a male researcher at the group of men. The mixed group was moderated by both. Once participants were introduced to each other, the topic of discussion was communicated, stressing that it was about exchanging ideas without considering some better than others, as different opinions only reflect different mindsets. Then, consent to videotape the sessions was asked, in order to transcribe, analyze, and eventually destroy the recordings. At that moment participants were informed that they could leave the group if they thought the subject was uninteresting, thus facilitating an acceptable excuse for those who might feel discomfort. 
Se acotaba el objeto de discusión excluyendo la trata de personas con fines de explotación sexual, por considerarlo un problema diferente para el objeto de estudio. La sesión se iniciaba sugiriendo algunos tópicos a través de preguntas formuladas desde el guión elaborado, sobre las que se invitaba a opinar o a plantear otros aspectos no sugeridos. Eran de tipo general y abierto, como por ejemplo: ¿Por qué creéis que existe la prostitución? ¿Por qué la ejercen las mujeres? ¿Por qué la consumen los hombres? ¿Es un problema social o es una cuestión individual? Enmarcado el tema, se dejaba que el discurso fluyera libremente, interviniendo sólo cuando fuera necesario reconducir la discusión en torno al tema. Para finalizar, se presentaba un resumen de las principales ideas recogidas, y se les invitaba a completarlo o comentar cualquier otro aspecto que no hubiera sido abordado y consideraran de interés.

\subsection{Instrumento}

Para el análisis de los datos se siguió el modelo propuesto por Rodríguez, Gil \& García (1996), a partir de Miles \& Huberman (1994), que identifica tres procesos clave: 1) reducción 2) disposición y transformación, y 3) obtención de resultados y verificación de conclusiones. El instrumento utilizado fue un sistema de categorías elaborado "ad hoc", siguiendo un proceso inductivo-deductivo, que incorpora tanto los ejes temáticos sustantivos del objeto de estudio, como los emergentes en el discurso de los participantes (Sánchez, Delgado \& Santos, 2012). La pertinencia y exhaustividad de las categorías fue evaluada por diez jueces expertos (cinco mujeres y cinco hombres), siendo el criterio de selección haber publicado sobre el tema en alguna revista científica en los últimos cinco años. Se estimó la credibilidad o validez interna del sistema de categorías mediante la concordancia entre jueces expertos, obteniendo un índice de correlación intraclase (CCl) satisfactorio para todas las categorías $(>0,40)$ como se muestra en la tabla siguiente. La dependencia o fiabilidad de las categorías se verificó a partir de las codificaciones de un fragmento textual, realizadas por cinco codificadores independientes a quienes se proporcionó el manual de descripción de las categorías, obteniéndose buena concordancia (coeficiente
The subject of the discussion was delimited excluding human trafficking for sexual exploitation, as it was considered a problem outside the field of study. The session began by suggesting some topics through questions from the prepared script, on which participants were invited to comment or raise other issues not suggested on it. Questions were general and open-ended, such as: Why do you think prostitution exists? Why do women work as prostitutes? Why do men use prostitutes? Is it a social problem or is it an individual matter? Framing the subject, the moderator let the conversation flow freely, intervening only when necessary to redirect the discussion back to the topic. Finally, a summary of the main ideas was presented, and they were invited to add to it or comment on any other issue that had not been addressed and they may consider of interest.

\subsection{Instrument}

For data analysis the model proposed by Rodriguez, Gil \& García (1996), from Miles \& Huberman (1994) was followed, which identifies three key processes: 1) reduction 2) arrangement and processing, and 3) verification of results and conclusions. The instrument used was a system of categories developed "ad hoc", following an inductive-deductive process, which incorporates both the substantive themes of the object of study, and the ones that emerged in the discourse of the participants (Sanchez Delgado \& Santos, 2012 ). The relevance and completeness of the categories was evaluated by expert judges (five women and five men), all of whom were selected for having published on the subject in a scientific journal in the last five years. Credibility or internal validity of the category system was estimated by agreement among the expert judges, obtaining an satisfactory index of intraclass correlation (ICC > 0.40) for all categories as shown in the following table. The Dependency or reliability of the categories was verified from encodings of a textual fragment, performed by five independent coders to whom the manual description of the categories was provided, obtaining a good correspondence (kappa coefficient $=0.73$ ). The following table sum-

[ 42 ] MARÍA CARMEN DELGADO ÁLVAREZ Y ANDREA GUTIÉRREZ GARCÍA

SIPS - PEDAGOGIA SOCIAL. REVISTA INTERUNIVERSITARIA [1139-1723 (2015) 26, 35-57] TERCERA ÉPOCA 
kappa $=0,73)$. La tabla siguiente resume los ámbitos de indagación de las categorías y el $\mathrm{CCl}$ obtenido para cada una de ellas:

Tabla 2. Ámbitos de indagación de las categorías principales

\begin{tabular}{|c|c|}
\hline CATEGORÍAS & ÁMBITOS DE INDAGACIÓN \\
\hline \multirow{3}{*}{$\begin{array}{l}\text { Contexto social } \\
\mathrm{CCl}=0,727\end{array}$} & Valores sociales \\
\hline & Socialización de género \\
\hline & Aspectos culturales \\
\hline \multirow{3}{*}{$\begin{array}{l}\text { Ejercicio de las mujeres } \\
\mathrm{CCl}=0,720\end{array}$} & Razones por las que ejercen prostitución \\
\hline & Aspectos a tener en cuenta \\
\hline & Consecuencias y efectos \\
\hline \multirow{3}{*}{$\begin{array}{l}\text { Demanda de los hombres } \\
\mathrm{CCl}=0,570\end{array}$} & Razones por las que demandan prostitución \\
\hline & Aspectos a tener en cuenta \\
\hline & Consecuencias y efectos \\
\hline \multirow{2}{*}{$\begin{array}{l}\text { Posición personal } \\
\mathrm{CCl}=0,973\end{array}$} & Posición anti-prostitución (abolir) \\
\hline & Posición pro-prostitución (regular o mantener) \\
\hline
\end{tabular}

Table 2. Areas of inquiry of the major categories

\begin{tabular}{|l|l|}
\hline \multirow{4}{*}{ Social ContextICC $=0.727$} & AREAS OF INQUIRY \\
\hline \multirow{4}{*}{$\begin{array}{l}\text { Women practicing prostitution ICC }= \\
\text { O.720 }\end{array}$} & Social values \\
\cline { 2 - 2 } & Gender socialization \\
\cline { 2 - 2 } & Cultural Aspects \\
\hline \multirow{3}{*}{ Men 's demandICC $=0.570$} & Aspects to consider \\
\cline { 2 - 2 } & Consequences and effects \\
\hline \multirow{3}{*}{ Personal PositionICC $=0.973$} & Reasons why they use prostitutes \\
\cline { 2 - 2 } & Aspects to consider \\
\cline { 2 - 2 } & Consequences and effects \\
\hline & Anti-prostitution position (abolish) \\
\cline { 2 - 2 } & pro-prostitution Position (To regulate or maintain) \\
\hline
\end{tabular}




\subsection{Resultados}

Para la codificación y análisis de las transcripciones se utilizó el programa Nvivo10, adoptando como criterio de división del discurso, las unidades de contenido temático (Rodríguez, Lorenzo \& Herrera, 2005; Flick, 2004). Se tomó como variable criterio la posición ante la prostitución, comparando los argumentos emergentes en cada una de las posiciones discursivas. Los resultados obtenidos se resumen en la tabla siguiente:

\subsection{Results}

For the coding and analyzing of the transcripts Nvivolo program was used, adopting thematic content units as criteria for division of speech (Rodriguez, Lorenzo \& Herrera, 2005; Flick, 2004). The position on prostitution was taken as the variable criteria, comparing the emerging arguments in each of the discursive positions. The results obtained are summarized in the following table:

Tabla 3. Argumentos en las posiciones discursivas

\begin{tabular}{|c|c|c|}
\hline Categorías & PRO-PROSTITUCIÓN & ANTI-PROSTITUCIÓN \\
\hline \multirow{7}{*}{ 1. Aspectos sociales } & 1. Relación contractual libre & 1. Objetualiza a la mujer \\
\hline & 2. Un trabajo cualquiera & 2. Comerciar con sexo es distinto \\
\hline & 3. Mejora la economía del país & 3. Siempre explota a las mujeres \\
\hline & 4. Libertad y relativismo moral & 4. No es ético \\
\hline & 5. Superar el conservadurismo & 5. Pseudomodernidad \\
\hline & 6. Una mera transacción comercial & \\
\hline & 7. Cumple una función social & \\
\hline \multirow{4}{*}{ 2. Ejercicio mujeres } & 8. Mejora la situación de la mujer & 6. Efectos negativos en la salud \\
\hline & 9. No es denigrante para la mujer & 7. Es estigmatizante \\
\hline & 10. Libertad de elección & 8. Hay alternativas para subsistir \\
\hline & & 9. Nunca es lección libre \\
\hline \multirow{2}{*}{ 3. Demanda hombres } & 11. Es inevitable, siempre existió & 10. Satisfacción sexual ilegítima \\
\hline & & 11. Desconocen si hay coacción \\
\hline
\end{tabular}

Table 3. Arguments in discursive positions

\begin{tabular}{|c|c|c|}
\hline Categories & PRO-PROSTITUTION & ANTI-PROSTITUTION \\
\hline \multirow{7}{*}{ 1. Social Aspects } & 1. Free contractual relationship & 1. Objectifies women \\
\hline & 2. It is as any other job & 2. Trading with sex is different \\
\hline & 3. Improves the country's economy & 3. It always exploits women \\
\hline & 4. Freedom and moral relativism & 4. It is unethical \\
\hline & 5. Overcoming conservatism & 5. Pseudomodernity \\
\hline & 6. A mere commercial transaction & \\
\hline & 7. A social function & \\
\hline \multirow{4}{*}{ 2. Women practicing it } & 8. Improving the status of women & 6. Negative health effects \\
\hline & 9. It isn't demeaning to women & 7. It is stigmatizing \\
\hline & 10. Freedom of choice & 8. There are alternatives to survive \\
\hline & & 9. It is never a free choice \\
\hline \multirow{2}{*}{ 3. Men's demand } & 11. It is inevitable, it has always existed & 10. Illegitimate sexual satisfaction \\
\hline & & 11. They do not know if there is any coercion \\
\hline
\end{tabular}

[ 44 ] MARÍA CARMEN DELGADO ÁLVAREZ Y ANDREA GUTIÉRREZ GARCÍA

SIPS - PEDAGOGIA SOCIAL. REVISTA INTERUNIVERSITARIA [1139-1723 (2015) 26, 35-57] TERCERA ÉPOCA 
Las posiciones discursivas contrastadas presentan una configuración narrativa diferenciada, cuyos nudos principales se exponen a continuación. No se incluye el análisis de diferencias por género que será abordado en trabajos posteriores, por superar los límites de este artículo. La identificación de la procedencia de los verbatims se realiza mediante la siguiente nomenclatura:

Go: Grupo de Mujeres $\quad+$ GM: Mujer en Grupo Mixto
G $^{\lambda}$ : Grupo de Hombres
$\partial^{\lambda} \mathrm{GM}$ : Hombre en Grupo Mixto

\subsubsection{Posición pro-prostitución}

1.5.1.1. Relación contractual libre. Se percibe como un acuerdo entre dos personas adultas que no es nocivo para la sociedad y es legítimo si no afecta a terceros: "No sé, vamos a regular algo que puede que te mate, hablando de la cocaína por ejemplo, ¿pero las prostitutas?" (G ${ }^{\lambda}$ ), "O sea, yo no veo mal que un hombre vaya de prostitutas, mientras no sea mi marido (risas). No, pero te quiero decir que no es una visión buá, éste que va ahí, etc. No sé, cada uno tendrá sus razones, yo no me voy a meter" († GM).

1.5.1.2. Un trabajo cualquiera. Es un medio, como otro cualquiera, para ganarse la vida; en todos los trabajos se "vende" algo de uno mismo: "Es una profesión, igual que si yo soy carpintero y hago una mesa para otro hombre, para tener ciertos recursos" (G $\left.{ }^{\top}\right)$.

1.5.1.3. Mejora la economía del país. Si se regulase permitiría recaudar impuestos por un trabajo que ahora no contribuye fiscalmente: "Económicamente hasta le vendría bien al país, porque hay un montón de dinero que no, que es dinero negro y demás, y no va a ninguna parte y está ahí... Puede arreglar la crisis" (GО̉).

1.5.1.4. Libertad y relativismo moral. La imagen negativa de la prostitución se debe el tabú en torno al sexo: "Me parece que entraría en tema de moralidades, si se debe o no se debe, tampoco o sea, creo que habrá mucha gente que haga muchas cosas peores en el ámbito personal sin cobrar dinero y nadie dice nada, entonces..." (GP).

1.5.1.5. Superar el conservadurismo. El estigma de la prostitución está ligado a posiciones conservadoras
The contrasting discursive positions show a distinct narrative configuration, the main points are outlined below. Analysis of gender differences is not included, as it will be addressed in further researches, as they out of scope for this article. The identification of the origin of the verbatims is done with the following naming convention:

\section{Go: Group of Women \\ qGM: Woman in Mixed Group \\ Gô: Men's Group \\ JGM: Man in Mixed Group}

\subsubsection{Pro-prostitution Position}

1.5.1.1. Free contractual relationship. It is perceived as an agreement between two adults, it is not harmful to society and is legitimate if it does not affect third parties: "I don't know, let's regulate something that can kill you, talking about cocaine for example, but prostitutes? " $\left(\mathrm{G} \hat{O}^{\hat{\prime}}\right)$, "I mean, I think it is ok for a man to pick up some prostitutes, as long as he is not my husband (laughs).No, but I mean it's not as if I think, oh, that disgusting guy... etc.. I don 't know, everyone has his reasons, and they are none of my business "( $(\mathrm{GM})$.

1.5.1.2. It's the same as any other job. It is a means, like any other, to make a living, in all jobs workers "sell" something of themselves "It is a profession, just as if I am a carpenter and make a table for a client to earn something in return" (G $\left.{ }^{\Uparrow}\right)$.

1.5.1.3. It improves the country's economy. If it were to be regulated the government could raise taxes for work that currently belongs to the black economy. "Economically speaking, it would be good for the country, because there is a lot of money that is black money, is not going anywhere and it is there ... It can fix the crisis' $\left(\mathrm{G}^{\lambda}\right)$.

1.5.1.4. Freedom and moral relativism. The negative image of prostitution is related to the taboo around sex: "I think it would be related to the morality issues, whether people should or should not, I mean, I think there are many people who do a lot of worse things in the personal field without charging money and nobody says anything, so ... "(GP).

1.5.1.5. Overcoming conservatism. The stigma of prostitution is linked to conservative positions and reli- 
y a la tradición religiosa que dan una imagen prejuiciada de ella: "Dependiendo de la educación que te hayan dado, de cómo lo veas, y de... una persona que tenga afiliación a grupos religiosos, políticos o pertenezca a alguna asociación seguramente verán la prostitución desde una determinada perspectiva...." (GP). "Depende en el ambiente donde se haya criado. Si es una persona que a lo mejor se ha criado en un ambiente conservador, posiblemente tenga unas ideas más firmes y más duras que una persona que la han criado, educado con libertad de pensar" (Gठ̂).

1.5.1.6. Es una mera transacción comercial. Las necesidades sexuales son igual de naturales que otras; por tanto, la prostitución es un negocio para responder a esta demanda: "Es igual que otra cosa. A ver, por ejemplo, si tú tienes hambre pues te vas y compras o te vas a un restaurante a comer (risas). No, pero es verdad que para ellos es una necesidad y la pueden satisfacer, pues van alli tan contentos" (GP).

1.5.1.7. Cumple una función social. Resuelve el problema de personas que no tienen otra forma de mantener relaciones sexuales: personas sin pareja, personas con discapacidad o con problemas para relacionarse: "Gente, por ejemplo, ¿no os parasteis nunca a pensar en gente deficiente mental por ejemplo?; ahí tienen un apoyo, o sea, fuera es muy difícil que consigan muchas veces tener relaciones, sé que es bastante fuerte lo que digo, pero..." ( $\widehat{\jmath} G M)$.

1.5.1.8. Mejora la situación de la mujer. Si se regulase, mejoraría la situación de las mujeres que la ejercen, al otorgarles derechos sociales, y mejoraría la visión que la sociedad tiene de ellas: "Ante todo (sería bueno) para la mujer, en el sentido de que ahora te llegan y eso, que te puede pasar cosas, llegar el tío y hacer un "sinpa"' $\left(\mathrm{G}^{\Uparrow}\right)$, "Ese es el tema, regularlo todo para que tengan los medios de salud correspondientes y los derechos correspondientes y las obligaciones correspondientes de cumplir las normas que se les pongan y ya está" (GP).

1.5.1.9. No es denigrante para la mujer. Nadie tiene derecho a juzgarlo como denigrante, si las mujeres lo aceptan para sí mismas: "Las que lo eligen libremente para ellas, tampoco tenemos derecho los de- gious traditions that give a biased picture of it: "Depending on the education they have given you, how you look, and ... anyone who belongs to a religious group or to any political association surely sees prostitution from a particular perspective .... "(GO). "It depends on the environment where one has grown up. If it is a person who maybe has grown up in a conservative environment, he or she possibly has firmer and harder beliefs than a person who grew up and was educated with freedom of thought " $(\mathrm{G}$ ') .

1.5.1.6. It is purely a business transaction. Sexual needs are just as natural as any other need, therefore, prostitution is a business that meets this demand: "It's like anything else. Let's see, for example, if you're hungry you go and buy food or you go to a restaurant and eat (laughs). No, but it's true, for them it is a need, and if they can meet that need going there, they will be happy with that " $(\mathrm{G}$ ) $)$.

1.5.1.7. A social function. It solves the problem of people who have no other form of sexual intercourse: single people, disabled people or people with relationship issues: "People, for example, have you ever thought of mentally handicapped people, for instance?, There they can get support, that is, normally, it is very difficult for them to have sex out there, I know it's pretty strong what I'm saying, but ... "( $\precsim \mathrm{G} M)$.

1.5.1.8. Improving the status of women. If it were regulated, the situation of women involved would be improved by granting social rights, and the view that society has of them would also change for the better: "First of all (it would be good) for women in the sense that now you arrive and things can happen, maybe the guy leaves without paying " $G$ J)," That's the thing, everything should be regulated so rights and employment benefits such as health care would be available to them, along with obligations to comply with rules, which should be applied " $(G \circ)$.

1.5.1.9. It is not demeaning for women. Nobody has the right to judge prostitution as something demeaning, if women accept it for themselves: "Those who freely choose it for themselves, we have no right to tell them that it is demeaning. She is the one who has

[ 46 ] MARÍA CARMEN DELGADO ÁLVAREZ Y ANDREA GUTIÉRREZ GARCÍA SIPS - PEDAGOGIA SOCIAL. REVISTA INTERUNIVERSITARIA [1139-1723 (2015) 26, 35-57] TERCERA ÉPOCA 
más a decirle a ella que se está rebajando. Ella es la que tendrá que decir, si lo ha decidido (...), para ella misma no se rebaja" (G $\left.{ }^{\lambda}\right)$.

1.5.1.10. Libertad de elección. Las mujeres tienen derecho a elegir el modo de ganarse la vida: "A lo mejor síque tenemos que cambiar ese pensamiento; las personas que se quieren vender a sí mismas, que se vendan y punto" (GP).

1.5.1.11. Es inevitable, siempre existió. Siempre ha existido y siempre va a existir, ya que satisface necesidades sexuales de la especie (hombres): "Siempre va a haber gente, hombres que busquen eso, porque puede ser, desde el aspecto evolutivo somos poligamos, sabes, como los monos" (G ${ }^{\lambda}$ ).

\subsubsection{Posición anti-prostitución}

1.5.2.1. Objetualiza a la mujer: Se produce una deshumanización de la mujer para su uso como objeto de consumo a través del pago: "Es que ya están pensando en la mujer como... ¿cómo qué?, como un objeto, como decir, bueno pues vamos ahí y nos lo pasamos bien un rato con ésta, con la que sea, ya no le ponen un nombre, no tratan a la mujer como mujer, como lo que es" (Gㅇ).

1.5.2.2. Comerciar con sexo es distinto. Lo que se compra en la prostitución no permite equipararla a otras empresas: "No lo puedes comparar como si fuese una empresa. Vamos a ver, una empresa obtiene unos bienes sabes de qué va, pero el sexo en su base no es algo para obtener dinero" (Gô).

1.5.2.3. Siempre explota a las mujeres. La mayor parte de los beneficios se los llevan terceras personases y no están dispuestas a que este negocio desaparezca: "Lo del problema éste de los puticlubs y demás que se anuncian de sobremanera y supuestamente son moteles, que alquilan habitaciones a quien quiera, en este caso a chicas y que luego ellas en las habitaciones hacen lo que quieran, ni de coña. O sea, si esto se quisiera parar o hacerlo ilegal de verdad de una manera, se haría" (Gふ̉).

1.5.2.4. No es ético. No debería plantearse la opción de regularizarla, por cuanto daría legitimidad a algo a say on the matter, if she 's decided (...), that is not demeaning for her " $(G$ ) $)$.

1.5.1.10. Freedom of choice. Women have the right to choose their way of living: "Maybe we do have to change that way of thinking, people who want to sell themselves, have the right to do so, period" (GP).

1.5.1.11. It is inevitable, it has always existed. It has always existed and will always exist, as it is satisfying sexual needs of the species (men): "There will always be people, men, who seek it, because it is possible that, according to the evolutionary aspect we are polygamous, you know, like monkeys" (G $\left.{ }^{\lambda}\right)$.

\subsubsection{Anti-prostitution Position}

1.5.2.1. It objectifies women: it's a dehumanization of women for their use as an object of consumption through payment takes place: "They are already thinking about women like... what, like an object, like saying, well, let's go there and have a good time with that one (girl) there, they don't call her by her name, they don't treat women as women, as what they are "(GP).

1.5.2.2. Trading with sex is different. Prostitution cannot be equated to other industries because of the service that is being sold "You can't compare it to any other company. Let's see, a company gets some benefits, you know how it works, but sex at its base is not something to get money for " $\left(\mathrm{G}^{\lambda}\right)$.

1.5.2.3. Prostitution always exploits women. Most of the benefits are taken by third parties who are not willing to let this business disappear: "This problem with whorehouses and the kind is that they are heavily advertised and supposedly they are motels that rent rooms to anyone, in this case girls, and they are entitled to do whatever they want with them, no way. So, if there was a real interest in stopping it or making it illegal, it would be stopped " $\left(\mathrm{G}{ }^{\top}\right)$.

1.5.2.4. It is unethical. the option of regulating it should not be considered, because it would legitimize so- 
que no es ético: "Yo también creo que regularizar vender el cuerpo de una mujer tampoco es muy ético (...) creo que la regulación sería abrir más las puertas a eso, cuando lo que hay que hacer es intentar cerrarlas" (GP),"Porque la gente cuando una cosa es ilegal lo ven mal, y cuando una cosa es legal ya lo ven bien" (Gふ).

1.5.2.5. Pseudomodernidad. Aunque se acepta supuestamente por "modernidad", nadie desea que personas cercanas la ejerzan: "Aquí ahora decimos todas muy modernas, sí, bueno prostitución no pasa nada, pero a ninguna le gustaría que su hija fuera prostituta por ejemplo, por mucho que ella quiera y que le apetezca" (Gq).

1.5.2.6. Efectos negativos en la salud. La prostitución afecta, entre otras cosas, al estado psicológico de las mujeres: "Yo creo que los efectos psicológicos, que yo no me puedo poner en ese lugar, ni ninguno de nosotros, seguramente. Las tías que acaban de hacer ese servicio, ¿cómo se tienen que sentir? Aunque lo hayan elegido, pero si es por necesidad, como no sea una adicta al sexo o una ninfómana, o le dé absolutamente igual cंcómo se tiene que sentir esa mujer después de haberlo hecho?" (GО̂).

1.5.2.7. Es estigmatizante. Provoca sentimientos de vergüenza en las mujeres que la ejercen, haciendo que lo oculten en su entorno: "De hecho, es lo que yo decía, que decían algunas que les daba vergüenza, como que no es una vida normal" (GP).

1.5.2.8. Existen alternativas para subsistir. Hay alternativas a la prostitución por muchas que sean las necesidades: "Yo consideraría que hay otras vías de trabajo mucho mejores, y preferiría ganar dinero de una forma más noble, que sería yendo a un trabajo haciendo no sé, lo que fuera, a acostándome con una persona" (G⿻).

1.5.2.9. Nunca es elección libre. Aunque tome la apariencia de elección libre, se impone como salida desesperada por la falta de recursos: "Sí, estás dando tu consentimiento, pero eso no quiere decir que tú quieras hacerlo. Si lo estás haciendo es por necesidad, es por la necesidad por lo que lo haces, no porque quieras" (GP). mething that is unethical, "I also believe that regulating the trade of women's bodies is not very ethical (...) I think the regulation would open more possibilities in that area, but what we need to do is to try to close them "(GP)," Because when something is illegal it is seen as something bad, but when it is legal, it is seen as good " $(\mathrm{G})$.

1.5.2.5. Pseudomodernity. Although supposedly accepted as "modernity", nobody wants people close to them to practice prostitution: "Here we think we are all very openminded, yes, well, prostitution is ok, but none of us would like their daughter to be a prostitute, for example, as much as she may want it " $(G \circ)$.

1.5.2.6. Negative health effects. Prostitution affects, among other things, the psychological wellbeing of women: "I think about the psychological effects, I can not put myself in that place, nor any of us, surely. The girls who have just done that service, how must they feel? \{o They may have chosen it, but if they do it out of necessity, and if the girl is not a sex addict or a nymphomaniac, or she doesn't care, how must that woman feel after she has done it? " $\left(\mathrm{G}{ }^{\top}\right)$.

1.5.2.7. It is stigmatizing. It causes feelings of shame in women who practise it, making them hide from their environment: "In fact, that is what I said, some of them said they were ashamed, as they think it is not a normal life" (GP).

1.5.2.8. There are alternatives to survive. There are alternatives to prostitution no matter how in need the woman may be: "I consider that there are other much better jobs, and I would rather make money in a more respectable way, I would be working in.. I don't know, whatever else, but sleeping with a person "(G⿻).

1.5.2.9. It is never a free choice. Even if it appears to be a free choice, it is imposed as a way out of a desperate lack of resources: "Yes, you are giving your consent but that does not mean you want to do it.If you're doing it, it is out of necessity, it is because of this necessity that you do it, not because you want to "(GP). 
1.5.2.10. Satisfacción sexual ilegítima. Los hombres pueden obtener la satisfacción sexual sin necesidad de recurrir a la prostitución: "Aunque sea cómodo; si tienes otra forma de satisfacerlo que no sea también denigrándote a ti o a otra persona es mejor hacerlo de ese modo, que yendo y soltando el fajo de billetes" (Gठ̂).

1.5.2.11. Desconocen si hay coacción. Siempre es ilegítimo acudir a la prostitución porque no se puede saber si es forzada, ya que las mujeres lo ocultan por miedo; muchas están amenazadas por terceras personas: "pero que es difícil saber si está coaccionada, porque normalmente si están coaccionadas no te lo van a decir" ( 9 GM).

\section{Discusión y conclusiones}

A la vista de los resultados expuestos, en ambas posiciones discursivas, son los aspectos sociales de la prostitución los que articulan el mayor número de argumentos, seguidos de las mujeres prostituidas, y enfocándose por último la demanda masculina de un modo periférico, sin ocupar un espacio propio en el debate.

Desde la posición pro-prostitución se focalizan los efectos positivos para la economía, articulando los argumentos en torno a la alternativa de subsistencia para las mujeres, tan legítima como cualquier otra, y al efecto positivo para la economía que se derivaría de la regulación. La prostitución se representa como un trabajo más, que podría contribuir a mejorar la economía mediante la tributación fiscal si estuviera regulada. A este núcleo argumentativo se le añade la función social de dar respuesta a necesidades sexuales de los hombres. La legitimidad ética de estos razonamientos es incorporada como elemento en la propia representación social de la prostitución, contra-argumentando al discurso antiprostitución al vincular las objeciones sociales con el "tabú sexual" construido por ideologías conservadoras y moral tradicional. Las mujeres son enfocadas en esta posición como beneficiarias de una posibilidad más de subsistencia en casos de necesidad, que pueden elegir libremente. Por último, el consumo de prostitución se aborda de un modo exculpatorio y justificativo, significándolo como necesidades ineludibles de la especie (sexualidad masculina) a las que responde mediante una rela-
1.5.2.10. Illegitimate sexual satisfaction. Men can get sexual satisfaction without resorting to prostitution: "Although it may be comfortable, if you have another way of satisfiying yourself that is not also deningrating yourself or someone else, it is better to do it that way than going around and throwing about your money " $\left(\mathrm{GO}^{\top}\right)$.

1.5.2.11. They don 't know if there is any coercion. It's always wrong to resort to prostitution because you cannot know if there is consent, because women hide it out of fear, as many of them are threatened by third parties: "but it's hard to know if she is coerced, because usually if they are, they won't tell you anything "(GMP).

\section{Discussion and Conclusions}

In view of the above findings, in both discursive positions, the social aspects of prostitution are the ones which articulate the largest number of arguments, followed by prostituted women, and finally, the male demand, but in a peripheral way, without occupying its own space in the debate.

From the pro-prostitution position, positive effects on the economy are raised, articulating arguments for alternative livelihood for women, as legitimate as any other, and the positive effect on the economy that would result from the regulation. Prostitution is represented as a job that could help improve the economy through fiscal taxation if it were regulated. In this argumentative core the social function of responding to the sexual needs of men is added. The ethical legitimacy of these arguments is incorporated as an element in the social representation of prostitution itself, counter-arguing the anti-prostitution discourse linking social objections as "sexual taboo" built by conservative and traditional moral ideologies. Women in this position are thought of as beneficiaries of another option in cases of necessity, which they can choose freely. Finally, the consumption of prostitution is addressed in an exculpatory and justifiable way, thinking of it as satisfying the unavoidable needs of the species (male sexuality) by responding to the contractual relationship between free adults regulated by supply and demand. 
ción contractual libre entre adultos, regulada por la oferta y la demanda.

Desde la posición anti-prostitución, el núcleo discursivo sobre los aspectos sociales adopta un foco diferente. Las cuestiones éticas emergen como elemento central, y las referencias al aspecto económico son filtradas por el juicio ético que cuestiona la explotación sexual de las mujeres. Aunque incipientemente, emerge la perspectiva de género al tematizar la "objetualización" de la mujer, como algo inherente a toda forma de prostitución; pero sin llegar a cuestionar cómo afecta a la representación social de todas las mujeres en el imaginario colectivo (Cobo, 2011). La argumentación sobre las mujeres prostituidas, irrumpe como el negativo del discurso pro-prostitución, con una coincidencia temática en los ejes principales. Se visibiliza su carácter degradante, la diferencia entre consentimiento y libertad de elección, y los efectos negativos para las mujeres consideradas víctimas del sistema. La prostitución, desde esta posición, no puede considerarse ni una elección libre ni la mejor opción por desesperada que sea la situación; es percibida como una alternativa estigmatizante y nociva.

El consumidor ocupa, también en este discurso, un papel periférico. La diferencia respecto a la posición pro-prostitución es que emerge como sujeto responsable y libre, y no como mero actor que responde a un imperativo atávico de la especie. Frente a la concepción "fatalista" de la inevitabilidad de la prostitución, resultado del determinismo biológico de la sexualidad masculina, en esta posición se construye la representación de las necesidades sexuales masculinas como algo controlable por los sujetos. No se cuestionan; pero se atribuye responsabilidad ética a los consumidores de prostitución en la forma de satisfacerlas. El eje argumentativo en esta categoría es de razón práctica, ya que su deslegitimación se articula en torno a la posibilidad de satisfacer estas necesidades incuestionadas, por otras vías que no comprometan su participación activa en un sistema de explotación de las mujeres, puesto que nunca es posible conocer si es ejercida bajo coacción. Así pues, el consumo es significado androcéntricamente como "necesidades sexuales de la especie", otorgando a la prostitución un carácter funcional (discurso pro-prostitución) o una forma inaceptable de satisfacerlas (discurso anti-prostitución); pero en ambos casos necesidades incuestionadas.
From the anti-prostitution position, the core discourse on the social aspects takes a different focus. The ethical issues emerge as a central element, and references to economics are filtered by the ethical judgment that questions the sexual exploitation of women. Although incipiently gender perspective emerges to make the central point that the "objectification" of women is something inherent to all forms of prostitution, the question of how it affects the social representation of all women in the collective imagination is not raised. (Cobo, 2011 ).This argument about women prostitutes breaks in as the opposite of the pro-prostitution discourse, with a thematic coincidence in the core ideas. Its degrading nature is made clearly visible, the difference between consent and choice, and the negative impact on women as victims of the system. Prostitution, from this position, cannot be considered neither a free choice nor the best choice, no matter how desperate the situation may be; it is perceived as a stigmatizing and harmful alternative.

The consumer occupies a peripheral role in this discourse as well. The difference with respect to the pro-prostitution position is that here he emerges as a responsible and free individual, not as a mere actor who responds to an atavistic imperative of the species. Facing the "fatalistic" view of the inevitability of prostitution, as a result of the biological determinism of male sexuality, in this position, the representation of male sexual needs is constructed as something that subjects are able to control. They are not questioned, but prostitution consumers are attributed ethical responsibility on how to meet their needs. The argumentative axis in this category is of practical reason, since its delegitimization revolves around the possibility of meeting these unquestioned needs in other ways that do not entail their active participation in a system of exploitation of women, since it is never possible to know if prostitution is practised under coercion. Thus, consumption is androcentricly considered as "sexual needs of the species", giving prostitution a functional nature (pro-prostitution discourse) or an unacceptable way to satisfy them (anti-prostitution discourse), but in both cases those needs are unquestioned.

While in the anti-prostitution discourse the female prostitute is symbolized as a "victim", in the pro-prostitution discourse she is symbolized as a

[50] MARÍA CARMEN DELGADO ÁLVAREZ Y ANDREA GUTIÉRREZ GARCÍA SIPS - PEDAGOGIA SOCIAL. REVISTA INTERUNIVERSITARIA [1139-1723 (2015) 26, 35-57] TERCERA ÉPOCA 
Si en el discurso anti-prostitución la mujer prostituida es simbolizada como "víctima", en el discurso pro-prostitución es simbolizada como "beneficiaria"; pero con independencia de la diversidad de significados, emerge la coincidencia de ambas posiciones en la definición del problema, aunque se concluya de modo antagónico. Esta "definición del problema" compartida en ambos discursos, deja indemne la cuestión del género. La exclusión de la perspectiva de género en la definición del problema, sólo incipientemente esbozada por el discurso anti-prostitución, sugiere un yacimiento de posibilidades de intervención, útiles para una educación/pedagogía social de la igualdad. El gran interés para una acción socioeducativa en perspectiva de género, es precisamente la coincidencia focal en la estructura profunda de las narrativas contrapuestas.

La introducción en el debate de nuevos argumentos que incorporen la perspectiva de género, permitiría ampliar el marco de la definición en ambos discursos. La cuestión de la masculinidad hegemónica tradicional (Vila, Sierra \& Martín, 2014) juega un papel de máxima relevancia en esta redefinición del problema, al cuestionar la construcción social de la sexualidad masculina que subyace en el modelo hegemónico tradicional. Esta visibilización del aspecto más relevante y menos cuestionado de la prostitución ofrece a la educación/pedagogía social una vía privilegiada de intervención. Por el contrario, la desatención a la estructura subyacente en el marco de la definición, al inhibir el debate sobre la cuestión estructural, deja indemne la cuestión de la desigualdad y la autoconciencia de la especie (De Miguel, 2012), así como la desigualdad de género evidenciada en la prostitución de las mujeres (Cobo, 2011) y la naturalización de sus cautiverios (Lagarde, 2011).

Una segunda conclusión a partir de estos resultados, es que la tematización del eje central del discurso (los aspectos sociales) es el único de los tres analizados, que se articula de forma diferente en las dos posiciones. Mientras en la posición pro-prostitución el núcleo discursivo es la consideración económico-laboral del problema, a la que se da legitimidad ética, en la posición anti-prostitución este núcleo central es ocupado por la consideración ética del problema, introduciendo la crítica moral a la visión economicista de la misma, y regulada por el mercado. La referencia introduce, aunque incipien- "beneficiary". However, regardless of the diversity of meanings, coincidence of both positions emerges in the problem definition, even though it is resolved in an antagonistic manner. This "problem definition" shared in both discourses, leaves the question of gender untouched. The exclusion of gender when defining the problem, only incipiently outlined by the anti-prostitution discourse, suggests a reservoir of intervention possibilities, which are useful for education / pedagogy of social equality. The great interest for an educational action in gender perspective is precisely the focal match in the deep structure of the competing narratives.

The introduction of new arguments that include gender perspective in the discussion, would broaden the scope of the definition in both discourses. The issue of traditional hegemonic masculinity (Vila, Sierra \& Martin, 2014) plays a role of utmost importance in this redefinition of the problem, questioning the social construction of male sexuality that underlies the traditional hegemonic model. This visibility of the most important and less questioned aspect of prostitution offers education / social pedagogy an exceptional manner of intervention. Conversely, failure to follow the underlying structure in the context of the definition, by inhibiting the debate on the structural issue, leaves untouched the question of inequality and self-awareness of the species (De Miguel, 2012) as well as the inequality of gender evidenced in the prostitution of women (Cobo, 2011) and the naturalization of their captivity (Lagarde, 2011).

A second conclusion from these results is that the theming of the central axis of the discourse (the social aspects) is the only one of the three analyzed which is articulated differently in the two positions. While the pro-prostitution position discursive core is about the economic and labor considerations of the problem, to which ethical legitimacy is given, in the anti-prostitution position this central core is occupied by the ethical consideration of the problem, introducing moral criticism against the economic view of it, regulated by the market. The reference introduces, although incipiently, the gender perspective in addressing the issue (the objectification of women).

The argumentative fissures in the anti-prostitution discourse allow the introduction of the issues 
temente, la perspectiva de género en la consideración del problema (objetualiza a la mujer).

Las fisuras argumentativas del discurso anti-prostitución permiten introducir la cuestión de los valores subyacentes y de la legitimidad del sistema en el que tiene cabida. Los efectos negativos para la salud y bienestar de las mujeres, la falta de libertad y el estado de necesidad que las lleva a prostituirse, la coacción bajo la cual se ejerce aunque se oculte por miedo, y la imposibilidad de equiparación con cualquier otro trabajo, son narraciones que permiten introducir el cuestionamiento del orden social en el que se legitima el modelo sexual patriarcal: 1) a qué intereses sirve, 2) quién se beneficia de ellos, 3) sobre quién recaen sus efectos perniciosos y perversos, 4) qué representación del sistema sexo-género legitima, 5) qué modelo antropológico sale reforzado y 6) qué implicaciones tiene para todas las mujeres y para la forma en que se establecen las relaciones entre los sexos. Si bien en la estructura superficial del discurso anti-prostitución no se cuestiona el modelo de sexualidad que subyace en la prostitución, la racionalidad que da soporte a las argumentaciones esgrimidas -al contrario de lo que sucede en el discurso pro-prostitución- da cabida a este cuestionamiento, de gran interés para una educación/pedagogía social de la igualdad.

Por otro lado, mientras el discurso pro-prostitución define la cuestión ética como algo propio de ideologías conservadoras y niega el carácter degradante para las mujeres (nunca se plantea para los hombres), el discurso anti-prostitución plantea la imposibilidad de equiparar el sexo a cualquier producto de intercambio mercantil. Si bien no se explicita cuál es la diferencia sustancial de "negociar con sexo", este argumento evidencia un resquicio en la consideración ética del problema. Sobre esta fisura es posible plantear la cuestión estructural y los valores subyacentes en el problema abordado, o lo que De Miguel (2012) denomina la cuestión de la autoconciencia de la especie: "si queremos construir un mundo en que se normalice el acceso reglado a un mercado de cuerpos de los que se pueda disponer para su uso sexual o no, y en el que mayoritariamente sean cuerpos de mujeres" (p. 51). Así pues, si bien ninguno de los dos discursos visibiliza el impacto de la prostitución sobre la cuestión de la igualdad de los sexos y las relaciones de do- of the underlying values and the legitimacy of the system in which prostitution has a place. The negative effects on the health and wellbeing of women, the lack of freedom and necessity that leads to prostitution, the coercion under which prostitution is practiced although it may be hidden because of fear, and the impossibility of equating it with any other job, are discourses that allow us to introduce the questioning of the social order in which the patriarchal sexual model is legitimated: 1) whose interests it serves, 2) who benefits from them, 3) who suffers its pernicious and perverse effects, 4) which representation of the sex-gender system it legitimizes 5) which anthropological model emerges reinforced and 6) what are the implications for all women and for the way in which the relationship between genders is established. While the surface structure of the anti-prostitution discourse is not questioned, the underlying model of sexuality present in prostitution, the rationality that supports the arguments put forward, -contrary to what happens in the pro-prostitution discourse accommodates this question of great interest for an education / pedagogy of social equality.

Furthermore, while the pro-prostitution discourse defines ethic issues as something belonging to conservative ideologies and denies the degrading nature of prostitution for women (this question never arises for men), the anti-prostitution discourse raises the impossibility of equating sex to any other product of commercial exchange. While it is not explicitly stated what is the substantial difference "of negotiating with sex", this argument reveals a loophole in the ethical consideration of the problem. Using this loophole it is possible to raise the structural issue and the underlying values of the approached problem, or what De Miguel (2012) referred to as the issue of self-consciousness of the species: "If we want to build a world in which the regulated access to a market of bodies available for sexual use or not would be normalized, and in which most of those bodies would be women bodies "(p.51). Thus, although neither of the discourses make visible the impact of prostitution on the issue of equality of the genders and the patriarchal domination relations which underly it, in the anti-prostitution discourse there are conditions for questioning the gender perspective, as it introduces -although implicitly- the pro-

[ 52 ] MARÍA CARMEN DELGADO ÁLVAREZ Y ANDREA GUTIÉRREZ GARCÍA SIPS - PEDAGOGIA SOCIAL. REVISTA INTERUNIVERSITARIA [1139-1723 (2015) 26, 35-57] TERCERA ÉPOCA 
minación patriarcal subyacentes en la misma, en el discurso anti-prostitución se dan las condiciones para un cuestionamiento en perspectiva de género, al introducir -aunque implícitamente- el problema del "cuerpo desencarnado" que se mercantiliza en la prostitución de las mujeres (Jónasdóttir, 1993), "proporcionando una manera de teorizar la sexualidad, las relaciones de género, y los intereses de género" (Jónasdóttir, 2011, p. 249). En el discurso pro-prostitución, la intervención requiere abrir paso previamente a la consideración de la perspectiva de género en el análisis del problema.

Más allá de las argumentaciones concretas, el análisis del discurso emergente pone de manifiesto la necesidad de reformular la definición del problema en el imaginario social, introduciendo la cuestión del género como elemento clave. Se hace necesario desplazar la focalización desde los individuos concretos hacia la cuestión estructural, en la que está en juego el modelo de las relaciones de género. Sólo así, es posible apelar a la implicación de todos los sujetos sociales, haciendo que se sientan concernidos por este problema, y plantear acciones socioeducativas que cuestionen su representación en las estructuras profundas de los discursos.

El debate, recurso óptimo para una acción socioeducativa crítica y transformadora (Ortega, 2008), puede abordarse desde diferentes metodologías. La teoría de los modelos organizadores de Piaget ofrece un sustrato adecuado para propuestas educativas críticas, a través de técnicas dirigidas a complejizar la representación del fenómeno de la prostitución, introduciendo elementos no contemplados desde la posición previamente adoptada. Esta metodología aplicada a la resolución de conflictos en el ámbito escolar (Moreno Marimón, 1996; Sastre \& Moreno Marimón, 2002), se ha mostrado como una herramienta útil al facilitar la conciencia sobre el papel de las emociones en la representación mental de los problemas sociales y la amplificación de perspectivas en el enfoque de los mismos. Si el objetivo de una pedagogía crítica es facilitar el desarrollo de personas libres y autónomas frente a la realidad construida, capaces de posicionarse responsablemente ante ella, la propuesta educativa no puede ser la inducción hacia una u otra posición, sino la facilitación de una construcción más compleja de la realidad, que integre en la conceptualización de la misma el mayor número posible de elementos. El desarrollo blem of the "disembodied body" which is commercialized in the prostitution of women (Jónasdóttir, 1993), "providing a way of theorizing sexuality, gender relations, and the gender interests "(Jónasdóttir, 2011, p.249). In the pro-prostitution speech, the intervention requires a prior opening to the consideration of gender in the analysis of the problem.

Beyond the specific arguments, the emerging discourse analysis highlights the need to reformulate the definition of the problem in the public imagination by introducing the issue of gender as a key element. It is necessary to shift the focus from specific individuals to the structural issue, in which the model of gender relations is at stake. Only in this way is it possible to involve all social subjects, making them feel concerned by this problem, and propose socio-educational actions to challenge its representation in the deep structures of the discourses.

The debate, optimal resource for a socio-critical and transformative action (Ortega, 2008), can be approached from different methodologies. The theory of the organizational model of Piaget provides a suitable substrate for educational questioning proposals, through techniques designed to give complexity to the representation of the phenomenon of prostitution, introducing elements not covered in the previously adopted position. This methodology applied to conflict resolution in schools (Moreno Marimon, 1996; Sastre Marimon \& Moreno, 2002), has proven to be a useful tool to facilitate awareness on the role of emotions in the mental representation of social problems and the amplification of perspectives in the approach thereof. If the goal of critical pedagogy is to facilitate the development of free and independent subjects able to face up to the constructed reality, and capable of positioning themselves responsibly before it, the educational proposal cannot be biased towards either position, but it should facilitate the construction of a more complex reality, which integrates the greatest possible number of elements in its conceptualization .Cognitive development comes through repetitions in increasing levels of complexity, as shown by the cognitive theories, so the debate as a teaching resource to enrich the representation of the problem of prostitution can become an effective resource driven by the theory of organizational models. Classic studies of cognitive dissonance (Festinger, 1957) 
cognitivo procede por reiteraciones en niveles de complejidad cada vez mayor, como muestran las teorías cognitivas, por lo que el debate como recurso pedagógico para enriquecer la representación del problema de la prostitución, puede convertirse en un recurso eficaz conducido desde la teoría de los modelos organizadores. Estudios clásicos de la disonancia cognitiva (Festinger, 1957) han mostrado la efectividad de adoptar posiciones epistemológicas divergentes para enriquecer el propio punto de vista. En el problema de la prostitución, en el que las posiciones sociales están tan polarizadas, el debate puede convertirse en recurso pedagógico cuando se enmarca en un contexto en el que su objeto no sea defender las posiciones adoptadas, sino adoptar el punto de vista contrapuesto desarrollando las argumentaciones rechazadas en el propio enfoque del problema. Esta adopción "artificial" del enfoque del problema, podría facilitar la experiencia de incorporar elementos nuevos en la representación de la prostitución, mediante el artificio pedagógico de tener que desarrollar las argumentaciones del punto de vista contrapuesto. Si como señalan Moreno Marimón y Sastre (2010, p. 75) "a partir de una misma situación, sujetos diferentes pueden construir modelos muy distintos, según los elementos que retengan como importantes en la situación, y según los que añadan como producto de relaciones e inferencias que establezcan", los argumentos detectados en este estudio, desde cada una de las posiciones contrapuestas, pueden constituir un buen punto de partida para diseñar situaciones educativas en el que este ejercicio sea posible. De este modo se facilitaría tanto la acción cognitiva de incorporar elementos no contemplados como significativos en la representación previa del problema (de la que parte el sujeto), como el desarrollo de conexiones nuevas entre los elementos, en el sentido indicado por las autoras citadas. La situación facilitadora de la experiencia en la que la perspectiva de género, por ejemplo, es inducida artificiosamente en la posición del sujeto, podría contribuir a esta amplificación de la representación cognitiva que sustenta la del enfoque adoptado. Si la conceptualización de la prostitución y la posición que se deriva de ella, incorpora elementos nuevos rechazados en la construcción selectiva de su representación, la acción educativa habrá sido coherente con el objetivo de facilitar un posicionamiento crítico ante los problemas sociales, más libre y responsable. have shown the effectiveness of divergent epistemological positions to enrich one's own point of view. In the problem of prostitution, in which social positions are so polarized, the debate can become an educational resource when framed in a context in which it is not intended to defend the positions taken, but to take the opposite point of view. Developing the rejected arguments is itself the approach to the problem. This "artificial" approach to the problem, could facilitate the experience of incorporating new elements in the representation of prostitution through the pedagogical device of developing the arguments of the opposed point of view. If as indicated by Moreno Marimon and Sastre (2010, p. 75) "from the same situation, different subjects can build many different models, depending on the elements they retain as important in the situation, and according to which they add as a result of relationships and inferences they establish ", the arguments detected in this study, from each of the opposing positions can be good starting points for designing educational situations in which this exercise may be possible. Thus, both the cognitive action to incorporate elements not considered significant in the prior representation of the problem (from where the subject comes), and the development of new connections among elements would be facilitated in the way indicated by the authors. The situation that facilitates the experience in which gender perspective, for example, is artificially induced in the subject position, could contribute to this amplification of cognitive representation underpinning the approach. If the conceptualization of prostitution and the position that derives from it, incorporates new elements rejected in the selective construction of its representation, the educational action will have been consistent with the objective of providing a criticalmore free and responsible- stance against social problems. 


\section{Referencias Bibliográficas / Bibliographic References}

Barahona, M. J., \& García, L. M. (2006). Los prostituidores en la prostitución. Crítica 940, 62-65.

Bas-Peña, E. (2014). Educación Social y Género. Presentación. Pedagogía Social. Revista Interuniversitaria(23), 13-20. doi: 10.7179/PSRI_2014.23.01

Bas-Peña, E., Pérez-de-Guzmán, V., \& Vargas, M. (2014). Educación y género. Formación de los educadores y educadoras sociales. Pedagogía Social. Revista Interuniversitaria, 2014(23), 95-119. doi: 10.7179/PSRI_2014.23.05

Billig, M. (1996). Arguing and Thinking: a rhetorical approach to social psychology. Cambridge: Cambridge University Press.

Bourdieu, P. (1998). La dominación masculina. Barcelona: Anagrama.

Bueno, J. R. (2011). Concepto de representación sociales y exclusión. Acciones e Investigaciones Sociales, 9, 24-57.

Canales, M., \& Peinado, A. (1994). Grupos de discusión. In J. M. Gutiérrez, Métodos y Técnicas Cualitativas de Investigación en Ciencias Sociales (pp. 287-316). Madrid: Síntesis.

Carrera, M. V. (2013). Educando Queer: el educador/a social como agente de subversión de género en la escuela. Revista Iberoameriacna de Educación(61/2), 1-12.

Cobo, R. (2011). Hacia una nueva política sexual. Las mujeres ante la reacción patriarcal. Madrid: Libros de la Catarata.

De Miguel, A. (2012). La prostitución de las mujeres, una escuela de desigualdad humana. Revista Europea de Derechos Fundamentales, 19, 49-74.

De Paula, R. (2000). Hablan las putas sobre práctias sexuales, preservativos y sida en el mundo de la prostitución. Barcelona: Virus.

Delgado, C., \& Gutiérrez, A. (2012). Prostitución: notas para un análisis psicosocial. De la coacción al consentimiento. In Á. Figueruelo, M. Del Pozo, \& M. León, lgualdad: Retos para el siglo XXI (pp. 39-58). Santiago de Compostela: Andavira.

Delgado, C., Sánchez, M., \& Fernández-Dávila, P. A. (2011). Atributos y estereotipos de género asociados al ciclo de la violencia contra la mujer. Universitas Psychologica, 17(3), 769-777.

Fernández, M.J. (2011). Calidad de vida y salud de las mujeres que ejercen la prostitución. Tesis Doctoral no publicada.Oviedo: Universidad de Oviedo.

Festiger, L. (1957). A Theory of Cognitive Disonance. Stanford, CA: Stanford University Press.

Flick, U. (2004) Introducción a la investigación cualitativa Madrid: Morata

Gimeno, B. (2012). La prostitución. Barcelona: Bellaterra.

González Pérez, T. (2010). Mujeres, educación y democracia. Revista de Educación(351), 337-359.

Gurdián, A. (2007). El Paradigma Cualitativo en la Investigación Socio-Educativa. San José (Costa Rica): CECC y $\mathrm{AECl}$.

Gutiérrez, A. (2012). Análisis de la imagen de la mujer prostituida en las noticias de la prensa digital. In Actas del I Congreso Internacional de Comunicación y Género, (pp. 846-871). Sevilla: Mad.

Heilemann, T., \& Santhiveeran, J.(2011). How do female adolescents cope and survive the hardships of prostitution? A content analysis of existing literature. Journal of Ethnic \& Cultural Diversity in Social Work: Innovation in Theory, Research \& Practice, 20, 57-76. doi: 10.1080/15313204.2011.545945

Hernández Sampieri, R., Fernández, C., \& Baptista, P. (2010). Metodología de la Investigación (5a ed.). México D.F.: McGraw-Hill.

Ibáñez, J. (1979). Más allá de la sociología. El grupo de discusión: técnica y crítica. Madrid: Siglo XXI.

Ibáñez, T. (1988). Ideologías de la vida cotidiana. Psicología de las representaciones sociales. Barcelona: Sendai.

Jodelet, D. (1986). La representación social: fenómenos, concepto y teoría. In S. Moscovici, Psicología Social II. Pensamiento y vida social. Psicología social y problemas sociales (pp. 470-494). Barcelona: Paidós. 
Jónasdóttir, A. G. (1993). El poder del amor ¿Le importa el sexo a la Democracia? Valencia: Cátedra. Jónasdóttir, A. (2011). ¿Qué clase de poder es "el poder del amor"? Sociológica, 26(74), 247-273.

Lagarde, M. (2011). Los cautiverios de las mujeres: madresposas, monjas, putas, presas y locas. Madrid: Horas y Horas.

López, R., \& Baringo, D. (2006). Nadie va de putas. El hombre y la prostitución femenina. Zaragoza: Organización Editorial S.L.

Martín Baró, I. (2006). Hacia una psicología de la liberación. Revista Electrónica de Intervención Psicosocial y Psicología Comunitaria, 2(1), 7-14.

Martín Baró, I., Aron, A., \& Corne, S. (1994). Writings for a liberation psychology. Harvard: Harvard University Press.

Meneses, C. (2007). Riesgo, vulnerabilidad y prostitución. In VV.AA., La prostitución, una realidad compleja (pp. 11-36). Madrid: Cáritas Española.

Miles, M., \& Huberman, A.M. (1994). Data management and analysis methods. In Denzin y Lincoln (eds.), Handbook of cualitative research (pp. 428-444). Londres: Sage Publication.

Moreno Marimón, M. (1996). De las estructuras a los modelos organizadores. Cuadernos de pedagogía, 244, 60-64.

Moreno Marimón, M., \& Sastre, G. (2010). Cómo construimos universos. Amor, cooperación y conflicto. Barcelona: Gedisa.

Moscovici, S., \& Hewstone, M. (1986). De la ciencia al sentido común. In S. Moscovici, Psicología Social II. Pensamiento y vida social. Psicología social y problemas sociales (pp.679-710). Barcelona: Paidós.

Moscovici, S., \& Olasagasti, M. (1981). Psicología de las minorías activas. Madrid: Morata.

Ortega, J. (2008). Educación social en la escuela. Presentación. Revista interuniversitaria de pedagogía social, 15, 5-12.

Osborne, R. (1991). Las prostitutas: una voz propia, Crónica de un encuentro. Barcelona: Icaria.

Piaget, J., \& García, R. (1989). Hacia una lógica de los significados. Barcelona: Gedisa.

Rodríguez, G.; Gil, J., \& García, E. (1996). Métodos de investigación cualitativa. Málaga: Aljibe.

Rodríguez,C., Lorenzo, O., \& Herrera, L. (2005). Teoría y práctica del análisis de datos cualitativos. Proceso general y criterios de calidad, SOCIOTAM, XV(2), 133-154.

Sánchez, M.C., Delgado, C., \& Santos, M.C. (2O12). El proceso de la investigación cualitativa. Manual de procedimiento. Zamora: Intras.

Sastre, G., \& Moreno Marimón, M. (2002). Resolución de conflictos y aprendizaje emocional. Una perspectiva de género. Barcelona: Gedisa.

Sau, V. (2000). Diccionario ideológico feminista (Vol. I). Barcelona: Icaria.

Watzlawick, P. (1980). La realidad inventada. Barcelona: Gedisa.

Vila, E. S., Sierra, J. E., \& Martín, V. M. (2014). Estudio narrativo sobre la experiencia de la paternidad en profesionales de la educación. Pedagogía Social. Revista Interuniversitaria, 23, 71-94. doi: 10.7179/PSRI_2014.23.04

Vygostsky, L. (1978). Pensamiento y Lenguaje. Madrid: Paidós.

\section{Notas / Notes}

${ }^{1}$ Este artículo recoge parte de la investigación COACCIÓN Y CONSENTIMIENTO: PROSTITUCIÓN Y POLÍTICAS PÚBLICAS (BOE no 41 de 17/O2/2011). Ayuda predoctoral de la Consejería de Educación, Cultura y Turismo del Gobierno de La Rioja, asociada al IV Plan Riojano I+D+| 2013-2016.

${ }^{1}$ This article incorporates part of the research on ENFORCEMENT AND CONSENT: PROSTITUTION AND PUBLIC POLICY (BOE n $\circ 41$ of 17/O2/2011).Predoctoral support from the Ministry of Education, Culture and Tourism of the Regional Government of La Rioja, associated with the IV Plan Riojano I + D + I 20132016.

[ 56 ] MARÍA CARMEN DELGADO ÁLVAREZ Y ANDREA GUTIÉRREZ GARCíA

SIPS - PEDAGOGIA SOCIAL. REVISTA INTERUNIVERSITARIA [1139-1723 (2015) 26, 35-57] TERCERA ÉPOCA 
2 En este estudio no se aborda la prostitución masculina por tratarse de un fenómeno distinto, de acuerdo con Sau (2000, p. 253) "la prostitución masculina no es simétrica a la femenina y en todo caso, hay que estudiarla en el contexto de la explotación del hombre por el hombre". Esta cuestión ha sido abordada en otros trabajos (Delgado y Gutiérrez, 2012; Gimeno, 2012).

2 In this study, male prostitution is not addressed as it is considered to be a different phenomenon, according to Sau (2000, p. 253) "male prostitution is not symmetrical to its female counterpart and in no case must be studied in the context of exploitation of man by man. "This issue has been approached in other works (Delgado and Gutierrez, 2012; Gimeno, 2012).

\section{CÓMO CITAR ESTE ARTÍCULO / HOW TO CITE THE ARTICLE}

Delgado Álvarez, M. C., \& Gutiérrez García, A. (2015). Aproximación cualitativa a las posiciones discursivas sobre la prostitución: perspectiva socioeducativa. Pedagogía Social. Revista Interuniversitaria, 26 35-57. DOI:10.7179/PSRI_2015.26.02

Fecha de recepción del artículo / received date: 27.IX.2013

Fecha de revisión del artículo / reviewed date: 15.XI.2013

Fecha de aceptación final / accepted date: 16.II.2014

\section{DIRECCIÓN DE LAS AUTORAS/ AUTHORS' ADDRESS}

María Carmen Delgado Álvarez. Andrea Gutiérrez García, Universidad Pontificia de Salamanca. Facultad de Psicología. C/ Compañía, 1-5. 37002. Salamanca. España.

Dirección de correo/e-mail: cdelgado@upsa.es; agutierrezga@upsa.es

\section{PERFIL ACADÉMICO / ACADEMIC PROFILE}

María Carmen Delgado Álvarez. Catedrática de Psicometría, Facultad de Psicología. UPSA. Codirectora del Postgrado "Género y Comunicación" de 2005 a 2008. UPSA. Directora del Postgrado "Intervención Multidisciplinar en Violencia de Género" de 2006 a 2011. UPSA. Docente invitada (Posgrado Oficial en Estudios de Género y Políticas de Igualdad, Universidad de Salamanca), Profesora supervisora de prácticas de investigación (Máster Oficial en Igualdad y Género en el Ámbito Público y Privado, Universidad Jaume I).

Andrea Gutiérrez García. Licenciada en Psicología. Máster Univeritario en Estudios Interdisciplinares de Género. Universidad Autónoma de Madrid. Postgrado Intervención Multidisciplinar en Violencia de Género. UPSA. Especialista en Género y Políticas de Igualdad. Universidad Rey Juan Carlos. 30 año de Beca FPU del IV Plan Riojano I+D+| 2013-2016. Profesora contratada en prácicas UPSA. Actualmente realizando estancia predoctoral en Universidad de Malmö (Suecia). Representante de España en la red europea de estudios sobre prostitución. 
